\title{
曲げを受ける高カボルト摩擦接合継手を有する 合成桁接合部の力学的挙動に関する実験的研究
}

\author{
山口 隆司 1 ・長井 正嗣 2 宮下 剛 3 • 戸田 圭彦 4 ・吉岡 夏樹 5 ・松岡 徹 6 \\ 1正会員 大阪市立大学大学院 工学研究科都市系専攻（干558-8585 大阪市住吉区杉本3-3-138） \\ E-mail: yamaguti@civil.eng.osaka-cu.ac.jp \\ 2正会員 長岡技術科学大学大学院 環境・建設系専攻（†940-2188 新潟県長岡市上富岡町1603-1） \\ E-mail: nagai@vos.nagaokaut.ac.jp \\ 3 正会員 長岡技術科学大学大学院 環境・建設系専攻（下940-2188 新潟県長岡市上富岡町1603-1） \\ E-mail: mtakeshi@vos.nagaokaut.ac.jp \\ 4学生員 大阪市立大学大学院 工学研究科前期博士課程（干558-8585 大阪市住吉区杉本3-3-138） \\ E-mail: toda@brdg.civil.eng.osaka-cu.ac.jp \\ 5正会員（株)駒井ハルテック 橋梁事業部（テ110-8547 東京都台東区上野1-19-10） \\ E-mail: yoshioka@komaihaltec.co.jp \\ 6 正会員 (株)横河ブリッジ 橋梁生産本部 大阪工場（†592-8331 大阪府堺市西区築港新町 2-3） \\ E-mail: t.matsuoka@yokogawa-bridge.co.jp
}

\begin{abstract}
本論文では，高力ボルト摩擦接合継手部を有する合成桁接合部の終局曲げ挙動を調べることを目的とし て, 模型桁の載荷実験を行っている．模型桁には高力ボルト摩擦接合継手部がす心゙り先行型となる場合と， 降伏先行型となる場合の二体を用意し, それぞれ床版の圧壊が生じるまで載荷を行い, 高力ボルト摩擦接 合継手部の設計方針が曲げ挙動に与える影響に注目している。また，高力ボルト摩擦接合継手部を有する コンパクト断面合成桁が，AASHTOで規定される塑性モーメントに達するかどうかについても注目してい る. 最後に, 合成桁接合部のすべり耐力の算定方法として, 床版と桁の塑性化を考慮した終局すべり耐力 を計算し実験結果との整合性を確かめている.
\end{abstract}

Key Words : high strength bolted friction joint, composite girder, plastic moment

\section{1. はじめに}

近年，我が国では，構造の一層の合理化を目指し，鋼 材の塑性域を有効に活用する合成林設設計法に関する 様々な研究が行われている ${ }^{1) 6}$. 一方, 欧米では, AASHTO-LRFD ${ }^{7} や$ Eurocode $^{8,9)}$ のように，合成枌の正曲げ 状態での終局強度として塑性モーメントを採用する設計 基準類が存在する.これらは道路橋示方書 ${ }^{10)}$ のような許 容応力度設計法ではなく, 限界状態設計法を基本として おり，これらによれば，正曲げを受ける合成枌の断面は 小型化・少部材設計が可能となり，総コストとして約 20\%低減できると言われている ${ }^{11)}$ ，しかしながら，限界 状態設計法により主林を設計する場合，我が国ではそれ にふさわしい高力ボルト摩擦接合継手の設計法が確立さ れておらず, 道路橋示方書で示される許容応力度設計法 によるしかないのが現状である. そのため，塑性モ一メ ントの考慮によって桁断面を小型化できる場合でも，設
計作用モーメントそのものに変化がないことから，必要 ボルト本数も変わらず, 結果として, 小型化された断面 を採用できないということも想定される.したがって， 合成桁の塑性強度を考慮できる高力ボルト摩擦接合継手 に関する設計法の確立が求められている ${ }^{12)}$. しかし，現 状では塑性強度に達する合成桁断面の継手として高力ボ ルト摩擦接合を用いる場合の力学性状は明らかにされて いない.

そこで，本研究ではコンパクト断面合成林の高力ボル 卜摩擦接合部のすべり以降を含む終局状態に至るまでの 力学的挙動の解明に主眼を置き, 高力ボルト摩擦接合部 の設計方針（すべり先行型/降伏先行型）をパラメータ とした模型桁を用いた載荷実験を行った。また，コンパ クト断面合成桁の高力ボルト摩擦接合部のすべり耐力の 試算を行い，合成桁の接合部の設計の際の高力ボルト摩 擦接合継手の設計方針について議論した. 


\section{2. 合成桁高力ボルト摩擦接合部載荷実験 ${ }^{13)}$}

（1）模型桁および載荷実験方法

図-1に本実験に用いた模型林の側面図および断面図を 示寸．全長8,300mm（支間8,000mm），支間中央にて高 カボルト摩擦接合により接合された合成桁である．載荷 実験は長岡技術科学大学大型実験棟にて行った.

本模型桁は，塑性中立軸が腹板上縁よりも上側に位置

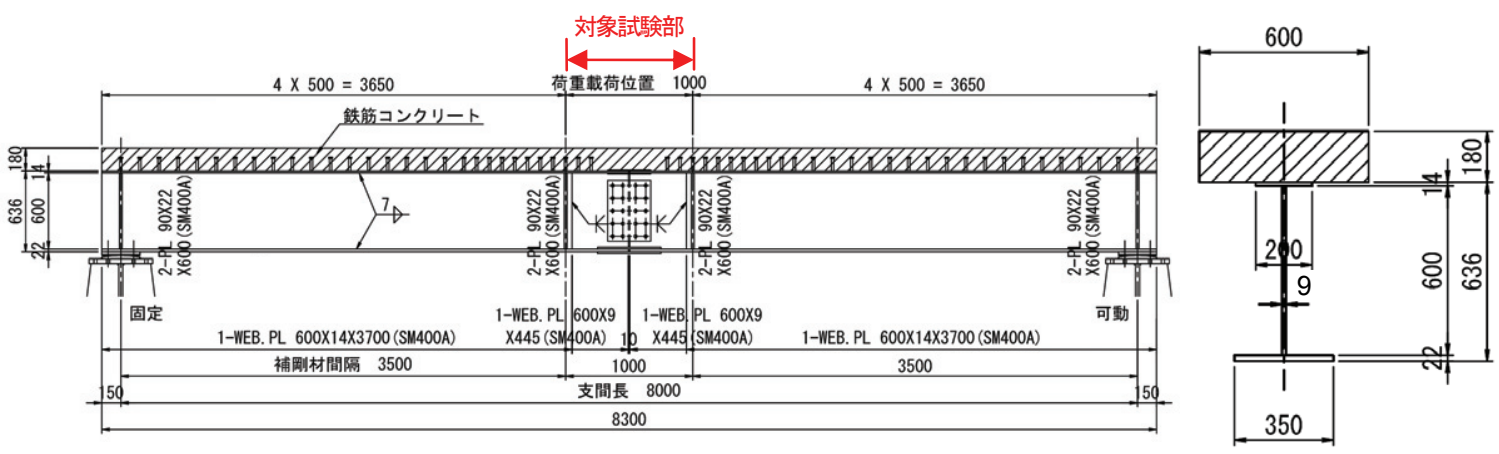

(a) 側面図

(b)断面図（対象試験部）

図-1＼cjkstart模型妳の形状と載荷および支点位置(単位：mm)

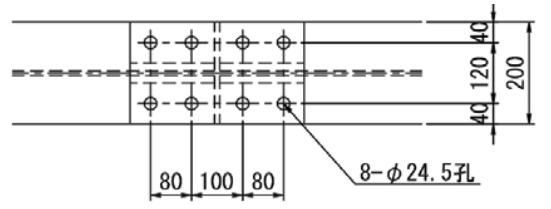

1-SPL. PL 200X 9X 340(SM400A) 2-SPL.PL 80X 9X 340 (SM400A) 8-HTB M22X75(F10T)

図-2上フランジのボルト配置(単位 : mm)

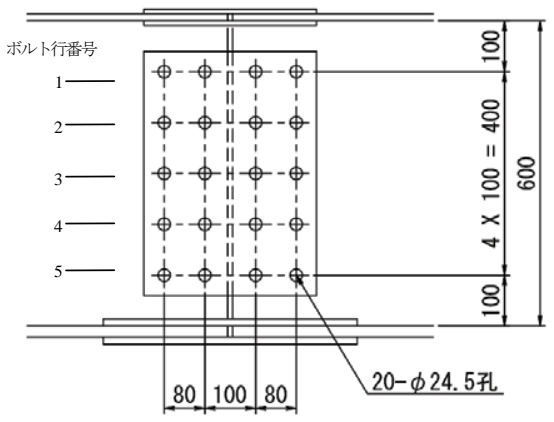

2-SPL. PL 480X 9X 340 (SM400A)

20-HTB M22X70(F10T)

図-3＼cjkstart腹板のボルト配置(単位 : mm)

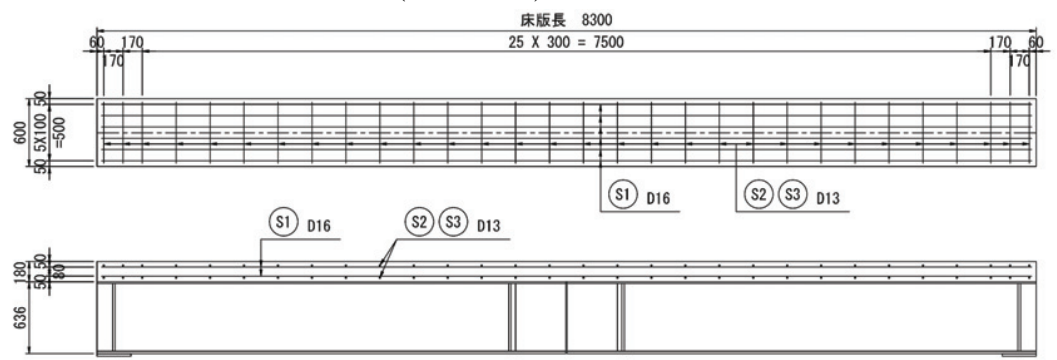

(a)一般図

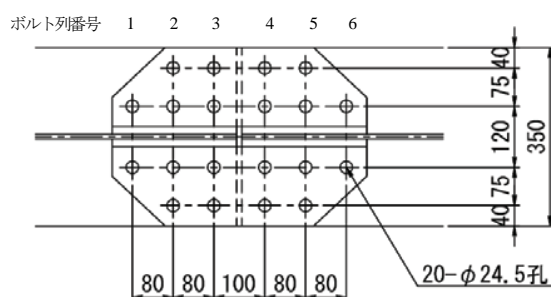

1-SPL. PL 350X14X 500 (SM400A)

2-SPL. PL 155X14X 500 (SM400A)

20-HTB $\mathrm{M} 22 \times 90$ (F10T)

(a)Type-1

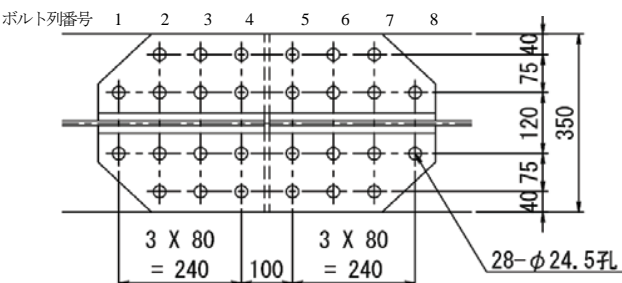

1-SPL. PL 350X14X 660 (SM400A)

2-SPL. PL 155X14X 660 (SM400A)

28-HTB M22X90(F10T)

(b)Type-2

図-4 下フランジのボルト配置(単位 : mm)

図-5 床版配筋図(単位 : mm)

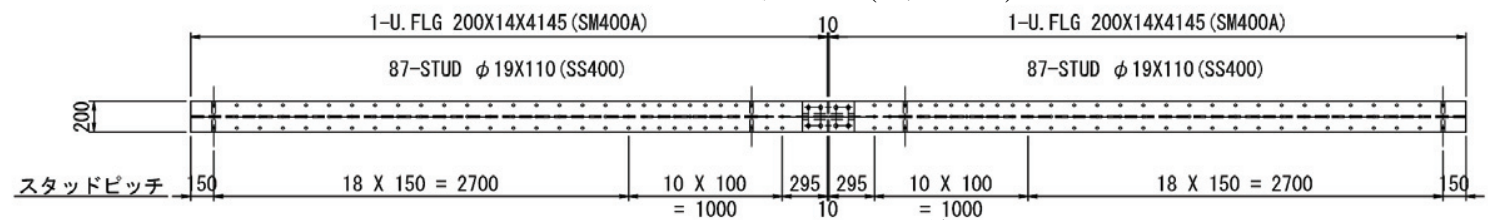

図-6 $=1000$ スッド配置図(単位 $: \mathrm{mm})$

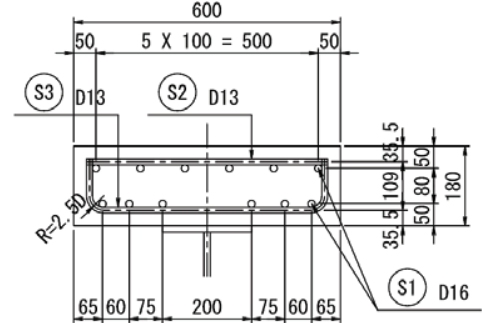

(b)断面図 


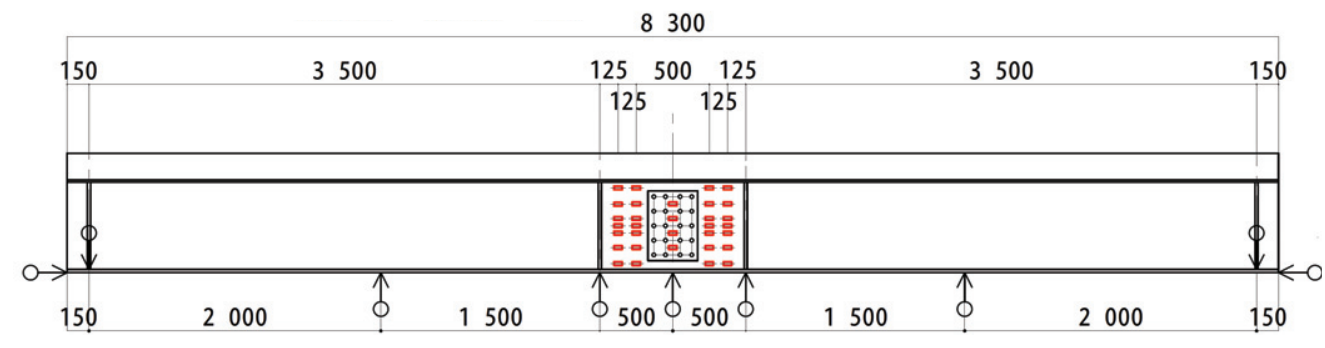

(a)側面図

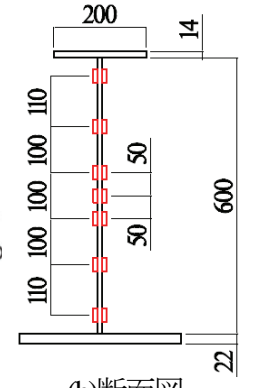

(b)断面図

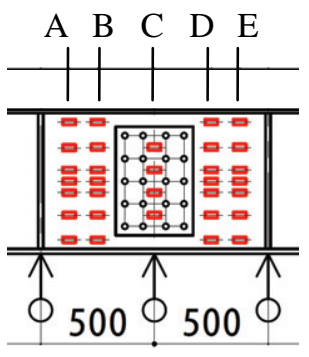

(c)腹板拡大図

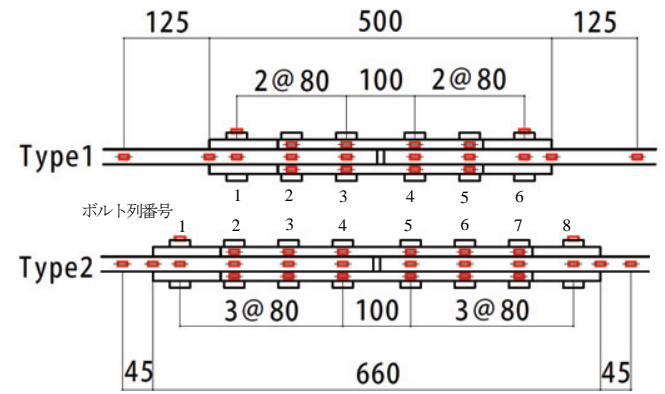

(d)下フランジ

(A,B,D,E 断面)

— : ひずみゲージ

亦位計

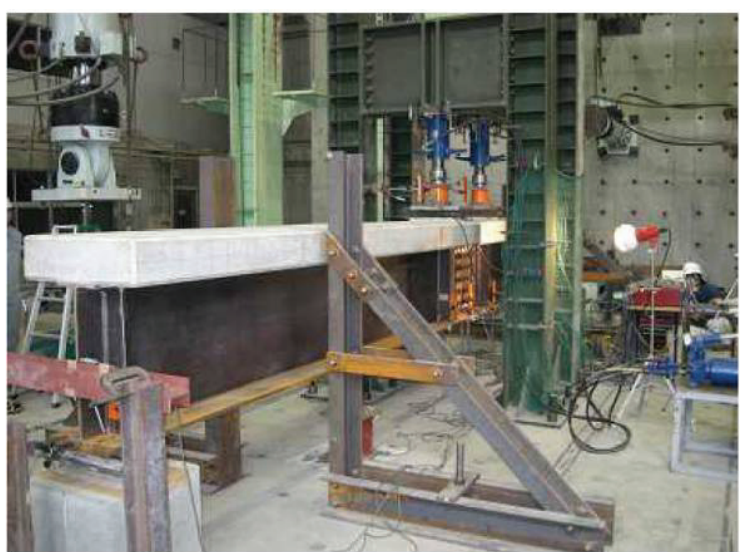

図-8＼cjkstart模型椼の設置状況

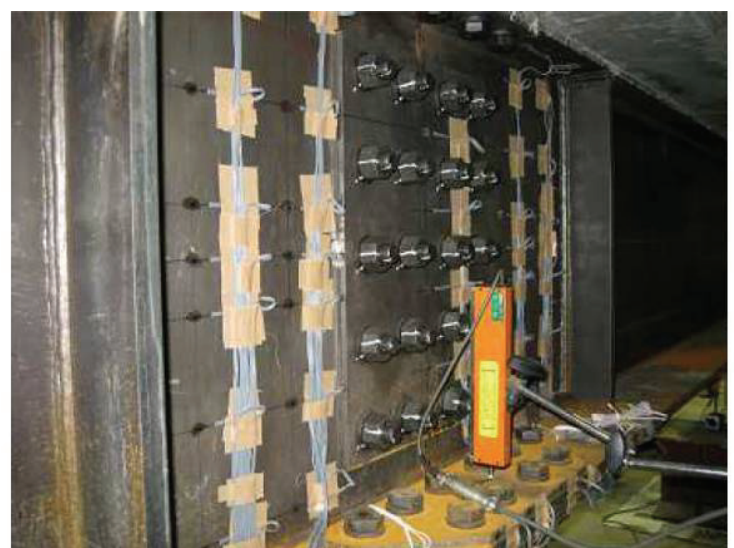

図-9 対象試験部の計測箇所の状況
することから，AASHTO (6.10.6.2.2) の断面区分による と，終局モーメントに達するコンパクト断面に分類され る.

模型析は, 下フランジのボルト本数が異なるType-1 (す心゙り先行型) とType-2 (降伏先行型) の2種類を用 意した．使用ボルトは，M22F10Tであり ${ }^{14)}$ ，ボルト孔径 は24.5mmである. 摩擦接合部のボルト本数は, 設計段 階ですべり係数を 0.5 , 母材の降伏点を $300 \mathrm{~N} / \mathrm{mm}^{2}$ と仮定 して計算している. Type-1（すべり先行型）では使用限 界としてすべり限界を定義し，使用限界に達するまです ベりが生じないように下フランジボルト本数を決定した. ここでは，使用限界すなわち，すべり限界をフランジの 総断面部分における降伏限界の87\%（下フランジの降伏 に対してすべりの発生時は1.15の安全率をとるものとす る）としている. また，終局限界状態として合成桁が塑
性モーメントに到達し, 鋼妳が全断面引張降伏している 状態を仮定して，鋼桁全体のボルト本数を決定している. Type-2では, Type-1に比べて下フランジのボルト列を一 列増やし，下フランジが降伏点に達するまでにすべりが 生じないようにしている．接合面処理はショットブラス 卜処理として, ブラスト処理後直ちにボルトの締結を行 った，腹板および上下フランジのボルト配置を図-2, 図 -3，図-4にそれぞれ示す。

模型枌の下フランジのすべり耐力降伏耐力比 ${ }^{15} は$ は, 事前に行った標準すべり試験で得られたすべり係数 0.43 を用いて Type-1（すべり先行型）で 0.81, Type-2（降伏 先行型）で 1.1 となった. なお，この際ボルト軸力は設 計ボルト軸力 205kN として算出した值である.

模型桁に使用した鋼材は全てSM400A材である.コン クリートは呼び強度 $40 \mathrm{~N} / \mathrm{mm}^{2}$ とし, ヤング率 $E_{\mathrm{c}}=3.1 \times 10^{4}$ 
表-1 鋼材の材料試験結果

\begin{tabular}{|c|c|c|c|}
\hline 部位 & $\begin{array}{c}\text { 降伏点 } \\
\left(\mathrm{N} / \mathrm{mm}^{2}\right)\end{array}$ & $\begin{array}{c}\text { 引張強度 } \\
\left(\mathrm{N} / \mathrm{mm}^{2}\right)\end{array}$ & $\begin{array}{c}\text { ヤング係数 } \\
\left(\mathrm{N} / \mathrm{mm}^{2}\right)\end{array}$ \\
\hline 上フランジ & 296 & 439 & $2.02 \times 10^{5}$ \\
\hline 腹板 & 321 & 457 & $1.98 \times 10^{5}$ \\
\hline 下フランジ & 283 & 439 & $1.88 \times 10^{5}$ \\
\hline
\end{tabular}

表-2 コンクリートの材料試験結果

\begin{tabular}{|c|c|}
\hline 材齢 $($ 日 $)$ & 圧縮強度 $\left(\mathrm{N} / \mathrm{mm}^{2}\right)$ \\
\hline 7 & 34.5 \\
\hline 28 & 44.4 \\
\hline 35 & 46.2 \\
\hline
\end{tabular}

$\mathrm{N} / \mathrm{mm}^{2}$ である ${ }^{10)}$. 表-1，表-2にそれぞれの材料試験の結 果を示す.

図-5に模型林の床版配筋図を示す。床板の鉄筋には SD295Aを用い，主鉄筋にD16，配力鉄筋にD13の異形鉄 筋を用いた．端部を除き，桁軸方向に $300 \mathrm{~mm}$ ピッチ，直 角方向に $100 \mathrm{~mm}$ ピッチで配置している．スタッドは，道 路橋示方書 ${ }^{10}$ を参照し，最大せん断力に対して十分安全 となるように配置した．図-6にスタッドの配置図を示す。 載荷には最大荷重1,000kNのジャッキ2台を用い，床版 の圧縮破壊もしくは接合部が終局限界状態に達するまで

（すなわち，荷重低下を確認するまで）静的に載荷した。

計測項目は，載荷荷重，鋼桁のひずみ，模型桁の鉛直 および水平変位，接合部の母板と連結板のずれ変位であ る. 図-7 に計測項目と計測位置を示す。ひずみゲージ の貼付位置は連結部における中立軸位置の確認，下フラ ンジ連結部における荷重伝達機構の解明を目的として決 定している. 図-8 に模型桁の設置状況，図-9 に対象試 験部の計測状況をそれぞれ示す.

計測は，荷重を確認しながらおよそ40kN間隔で手動 で計測を行った。その都度床版のひび割れの有無を目視 により確認した。ボルトのすべりが生じた場合について は，そこで載荷状態を維持し，計測を行った。

\section{（2）載荷実験結果}

\section{a) 荷重 - 変位関係と終局状態}

図-10にType-1およびType-2の荷重-変位の関係をそれぞ れ示す，変位は支間中央の鉛直変位である。図中 $P_{y g}$ は 鋼桁の総断面で， $P_{y n}$ は純断面の1.1倍で計算した模型桁 の降伏モーメント時の荷重（降伏荷重）である．算出に あたっては，断面積の公称值，材料試験から得られた降 伏点 $\sigma_{y}$ を用いている. $P_{p A A g}, P_{p A A n}$ は式 (1), (2)を用いて 計算を行ったAASHTOのDuctility条件を適用した終局モ 一メント時の荷重（終局荷重）であり，前者が総断面積
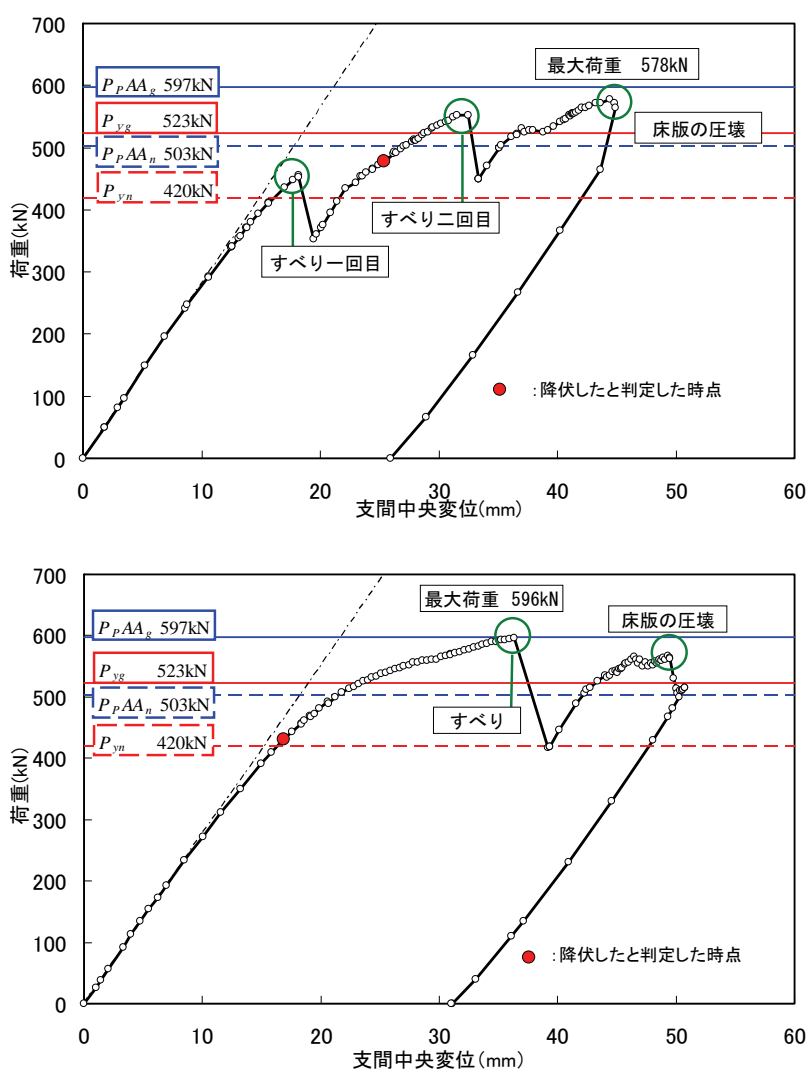

図-10 荷重-変位関係（上 : Type-1, 下: Type-2)

で，後者がボルト孔を控除した純断面積で計算している. AASHTOでは，塑性中立軸位置によっては合成断面が塑 性モーメントに到達する以前に床版コンクリートの圧壊 が先行する場合を考慮し，塑性中立軸位置によって塑性 モーメントを低減させたものを終局モーメントとしてい る. ここで，降伏モーメントは下フランジ下面が降伏に 到達した時と仮定し，式(3)より算出した。また，図中 には，式(4)より求めた模型林の孔引きを考慮しない断 面での理論初期剛性を一点鎖線で示すとともに，載荷中 に発生したイベントをロ内に示す.

終局モーメント $M_{u}$

\section{AASHTOのDuctility条件}

$$
\begin{aligned}
M_{u}= & M_{p}\left(D_{p} / D_{t} \leq 0.1\right) \\
= & \left(1.07-0.7\left(D_{p} / D_{t}\right)\right) \cdot M_{p} \\
& \left(0.1<D_{p} / D_{t}<0.42\right) \\
M_{p}= & 0.85 \cdot f_{c}^{\prime} \cdot A_{c} \cdot y_{c}+\sigma_{y} \cdot A_{s} \cdot y_{s}
\end{aligned}
$$

降伏モーメント $M_{y}$ および支間中央変位 $\delta$

$$
\begin{aligned}
& M_{y}=\sigma_{y} \cdot I / y_{l f} \\
& \delta=\frac{P \cdot a}{24 E I}\left(3 l^{2}-4 a^{2}\right)
\end{aligned}
$$

ここに

$$
M_{u}: \text { 終局モーメント }
$$


$M_{p}$ : 塑性モーメント

$D_{p}$ : コンクリート床版上面から塑性中立 軸までの距離

$D_{t} \quad$ : 合成断面の全高

$f_{c} \quad:$ コンクリートの圧縮強度

$A_{c} \quad$ : コンクリート床版断面積

$y_{c} \quad$ : 塑性中立軸からコンクリート床版図 心位置までの距離

$\sigma_{y}:$ 降伏点（鋼材）

$A_{s}:$ 鋼析の断面積

$y_{s}$ : 塑性中立軸から鋼桁図心位置までの 距離

$M_{y}:$ 降伏モーメント

$I$ : 合成断面の換算断面二次モーメント

$y_{l f}$ : 中立軸から下フランジ下縁までの距 離

E : 鋼材のヤング率

$a$ : 支点から載荷位置までの距離

$l \quad$ : 支点間距離

実験結果と式(1)〜(4)を用いた計算值との比較を表-3 に示す．実験結果の降伏荷重は，下フランジに貼付した いずれかのひずみゲージより得られた橋軸方向ひずみが, 降伏ひずみに達した時点としている．両試験体とも，第 二列ボルト孔付近のひずみが最初に降伏ひずみに至った. この試験体は第一列が 1 行少ないボル卜配列となってい るため，より荷重分担量が多い第二列が先行して降伏す る. 図-10 に示寸赤点は降伏荷重 (実験值) を示してい る.

すべり先行型である Type-1 は，計算で求めた総断面 降伏荷重 $P_{y g}$ に達する前にすべりが生じている. 一方, 降伏先行型である Type-2 では総断面降伏荷重 $P_{y g}$ 到達以 後にすべりが発生している，実験で得られた降伏荷重は， 総断面で求めた計算值に対して Type-1 では約 91\%,

Type-2 では約 82\%であった。 また，純断面積で計算し た $P_{y n}$ と比較すると, Type-1の実験值は計算值の約 114\%, Type-2の実験值は計算值の約 103\%に達した.

Type-1および Type-2 ともに明確なすべりが生じた際に 著しい荷重の低下が認められたが，さらに荷重を加える ことで荷重は上昇し, Type-1 の最大荷重は AASHTO LRFD による総断面での終局荷重 $\left(P_{p A A g}\right)$ の約 $97 \%$ となり, Type-2 の最大荷重は, 同様にほぼ $P_{p A A g}$ となった。また, 最大荷重を純断面の終局荷重 $\left(P_{p A A n}\right)$ と比較すると, Type1 は約 115\%, Type-2は $P_{p A A n}$ の約 118\%に達した.

両模型行の荷重-変位関係はType-1のすべり発生までは ほぼ一致する，すべり先行型のType-1では，降伏荷重が 降伏先行型のType-2に比べてやや大きくなったが，降伏 先行型のType-2では概ね計算值で下フランジ降伏に至っ た.しかし，荷重変位関係ではさらに低い荷重において
表-3 実験結果と計算值との比較

\begin{tabular}{|c|l|c|c|c|}
\hline \multirow{2}{*}{ 降伏荷重 } & \multicolumn{2}{|c|}{\begin{tabular}{c} 
計算值 $(\mathrm{kN})$ \\
\cline { 3 - 3 }
\end{tabular}} & $P_{y g}$ & \multicolumn{2}{|c|}{ 実験值 $(\mathrm{kN})$} \\
\cline { 2 - 3 } & $P_{y n}$ & 423 & \multirow{2}{*}{478} & 431 \\
\hline \multirow{2}{*}{ 終局荷重 } & $P_{p A A g}$ & 597 & \multirow{2}{*}{578} & 5 \\
\cline { 2 - 3 } & $P_{p A A n}$ & 503 & & Type-2 \\
\hline
\end{tabular}

$P_{y g}:$ 総断面降伏荷重, $P_{y n}:$ 純断面降伏荷重

$P_{p A A g}$ : 総断面終局荷重, $P_{p A A n}$ : 純断面終局荷重

非線形性が現れている。これは，測定したひずみは下フ ランジ側面の橋軸方向ひずみのみであり，かつ測定位置 も限られており，より早い段階でその他の部分が降伏に 至っていた可能性がある. 特に, ボルト孔周辺の応力集 中や下フランジと腹板との溶接箇所などの残留応力が合 成桁の初期降伏に影響を与えている1)ことが考えられる。

最大荷重に着目すると, すべり先行型であるType-1で は床版の圧壊により最大荷重となったが，AASHTOで述 ベられている終局モーメントに達しなかった。 これが推 定值を下回った原因としては，先行して発生した接合部 のすべりによって床版ひずみが増加し, 床版が圧壊した ためと考えられる. また，終局時の支間中央のたわみ量 も，すべりによる連結板のずれによって大きくなってい る.

一方，降伏先行型であるType-2ではAASHTO終局モー メントに達した. Type-2の最大荷重は床版の圧壊が発生 するより以前の，すべりが発生した時点であり，この時 の荷重は終局モーメントにほぼ等しかった。また，こち らもすべり後の床版ひずみ増加によって, 終局モーメン 卜に比べて低い荷重で床版圧壊に至ったものと考えられ る.

本実験では，総断面での塑性中立軸が模型桁の上フラ ンジ内にあることから，コンクリート床版上面の圧壊に 至るまで，図-11に示すようにコンクリート床版下面に ひび割れが生じることはなかった。

載荷後の腹板の連結部の様子を図-12に，下フランジ の連結部を図-13および図-14にそれぞれ示す. 図-12よ り，下フランジに近い腹板および下フランジ連結部にお いて，連結板と母板の間に相対ずれが認められる。しか し，上フランジに近い腹板および上フランジ接合部では 両者の相対ずれは認められなかった。 また，図一13およ び図-14より，ボルト孔周辺に金属光沢が認められ，す ベりが発生したことが確認できる.さらに， Type-2につ いては，母板および連結板の最外列ボルト孔が支圧変形 により円形からわずかに楕円形へと変形しているのがわ 
かる.

b) ひずみ分布と中立軸位置

図-15および図-16に，Type-1およびType-2の腹板にお

ける母板と連結板のひずみ分布の変化をB断面を例にそ
れぞれ示す。ここでは，載荷点や溶接ビードの影響が少

ないこと，および対称性を考慮し，B断面を例としてい る. 図の縦軸は下フランジ下面からの距離を表している. 合成桁の中立軸は総断面，純断面それぞれの場合におい

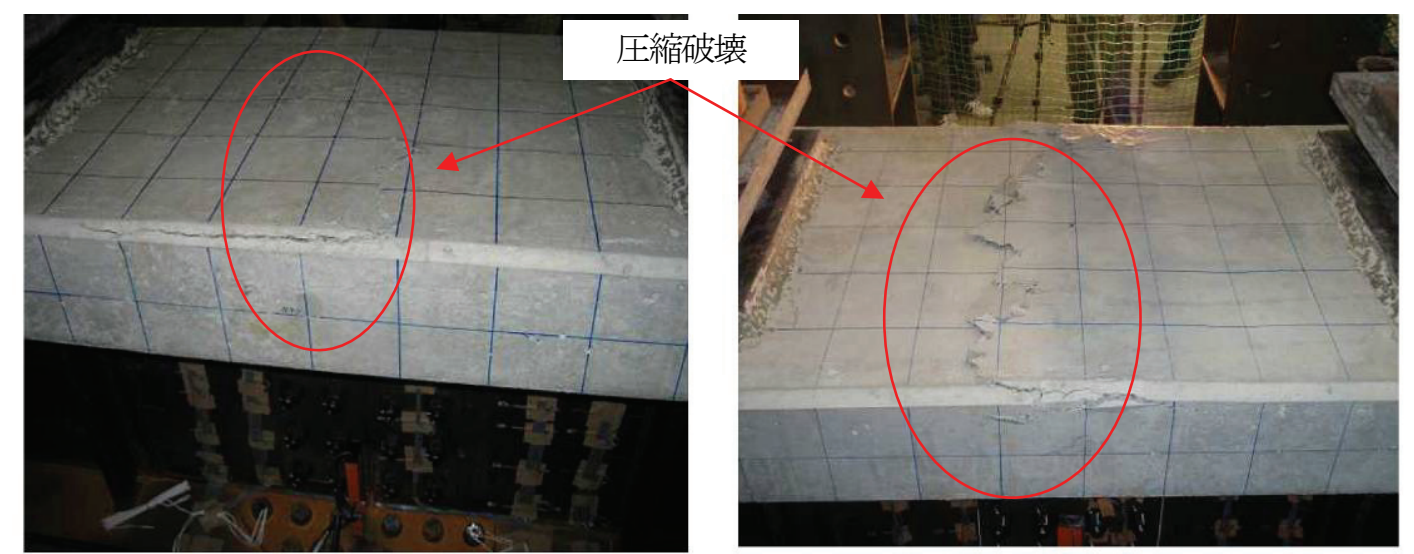

図-11 コンクリート床版上部の圧壊(左 : Type-1, 右 : Type-2)

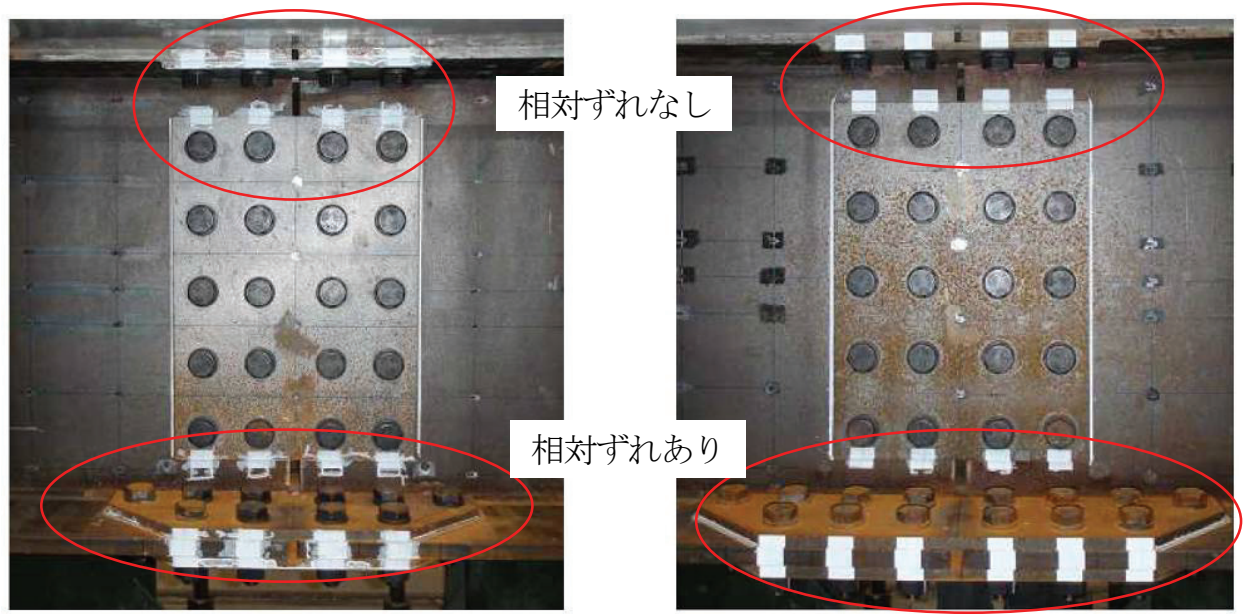

図-12 母板と連結板のずれ(腹板連結部)(左 : Type-1, 右 : Type-2)

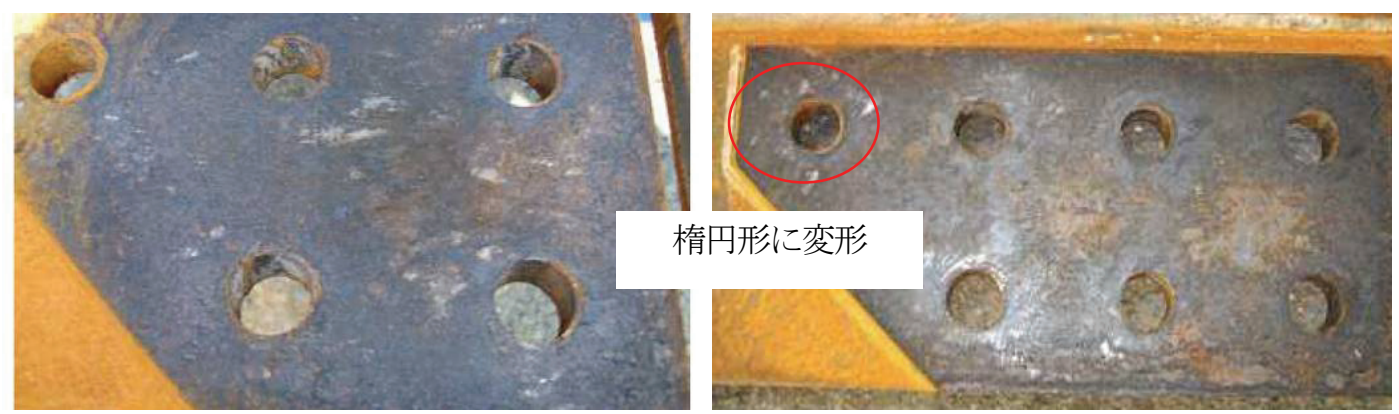

図-13 載荷後の下フランジ母板(左 : Type-1, 右 : Type-2)
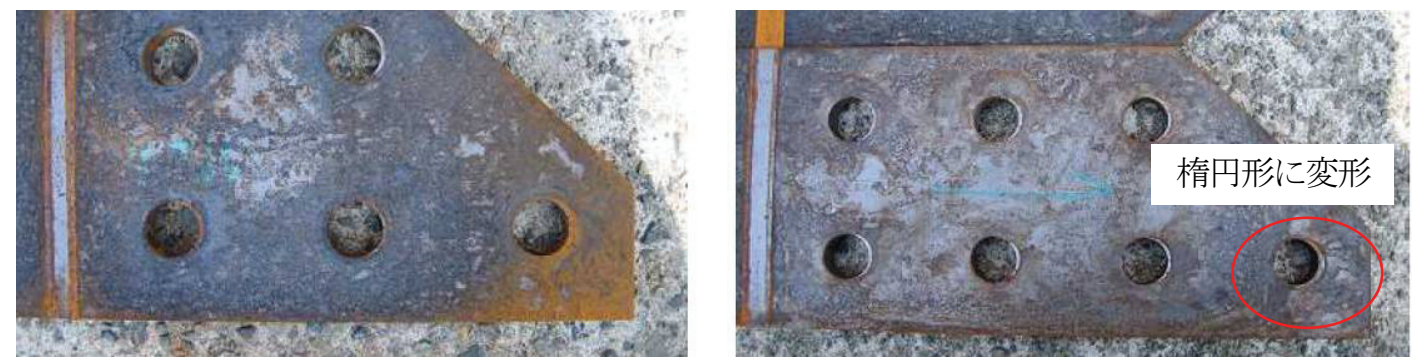

図-14 載荷後の下フランジ連結板(左 : Type-1, 右 : Type-2) 
て求め, その際圧縮領域の鉄筋は考慮していない. 計算 の結果，総断面積では下フランジ下面から弾性中立軸は 493mm，塑性中立軸は632mmとなった。純断面積では， 弾性中立軸は526mm，塑性中立軸は650mmであった。参 考のために総断面で求めた弾性中立軸位置および塑性中 立軸位置を図-15中に示している．計測值から導かれる 中立軸位置は弾性中立軸位置の計算值と良い一致を示す さらに，両試験体とも最大荷重時に観測された中立軸位 置は，塑性中立軸位置の計算值にほぼ一致した。

Type-1およびType-2ともに，荷重が小さい範囲（弾性 域）では，母板のひずみは高さ方向にほぼ線形に変化し， 同困内に示す弾性梁理論から導かれるひずみ分布にほぼ 一致する.ただし，フランジに近い測定箇所ではひずみ は異なっている．下フランジと最も近い測定位置は，連 結板下縁よりも下側に位置するため，周囲に比べてひず みの増加量は少なくなっている. すなわち，B断面内の 位置が連結板に近く，腹板内の忘力は腹板連結板の高力 ボルト周辺より伝達されるが，腹板連結板の大きさは腹 板高より小さく，フランジに近い腹板部では応力が減少 しているためと考えられる.

すべり先行型であるType-1では下フランジ接合部の大 きなすべりによる影響で，腹板上部のひずみが増大し， 中立軸の位置が塑性中立軸付近にまで移動している。 そ の後，床版の圧壊で最大荷重に至るまで中立軸の移動は 小さい.

すべり前後に注目すると，下フランジに近い腹板の下
部ではひずみが開放され小さくなり, その上部では逆に ひずみが増大するという傾向にあることがわかる：この ようなすべりによってひずみが解放される箇所と増大す る箇所の関係から，二回のすべり挙動を予測することが できる．図-15(a)によると，一回目のすべり時には下フ ランジ付近と腹板最下行（5行目）付近でのひずみ減少 がみられ，それ以外ではひずみ増加が認められることか ら，一回目のすべりは下フランジと腹板5行目のみがす ベったと考えることができる. 一方，図-15(c)によると 二回目の寸べり時には腹板の大部分でひずみが減少して おり，下フランジにおいてもひずみ減少が認められる.

したがって，一回目のすべり時には下フランジと腹板5 行目ですべりは発生したものの，連結板全体がすべって はおらず，二回目のすべりで主すべりに至ったと判断で きる.

降伏先行型である Type-2 ではType-1と異なり，約 $600 \mathrm{kN}$ まで大きなすべりが発生せず，段階的に中立軸が 上に移動している（図-15(b)）。すべり発生直前では桁 の大部分が塑性域に入っているため, す心゙り前後での中 立軸位置の大きな変動は見られない.ひずみの分布に着 目すると, 腹板5行目ボルト付近でのひずみは，降伏荷 重を超えたあたりからひずみの増加の程度が緩やかとな る.しかしそれに対して，最も下フランジに近い測定箇 所ではひずみが上昇を続ける。これは腹板5行目ボルト において部分すべりが下フランジ連結部のすべりに先行 しておきていたためと考えられる.

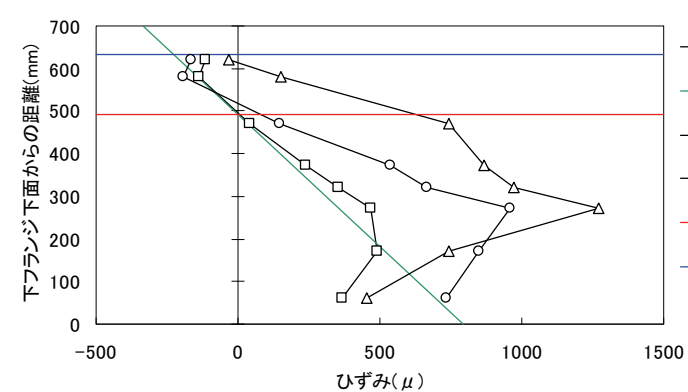

(a) Type-1 一回目す心゙り前後

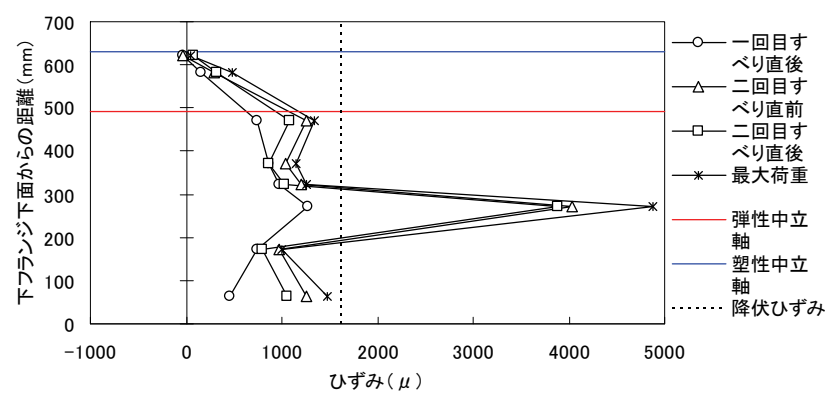

(c) Type-1 二回目すべり以降

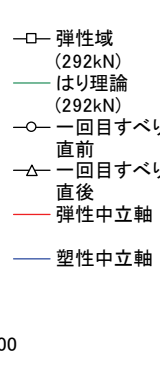

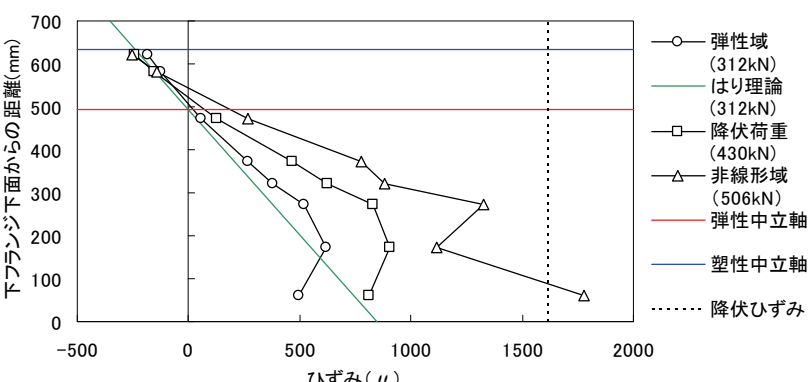

(b) Type-2 降伏前後

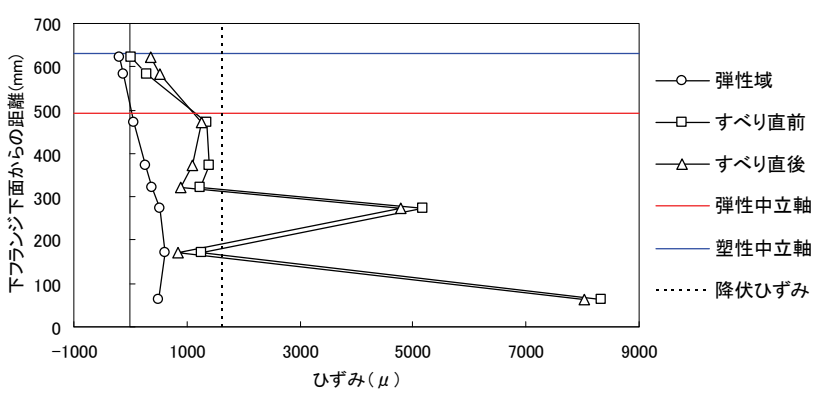

(d) Type-2 すべり前後

図-15 腹板のひずみ分布（B断面） 
ボルト列番号
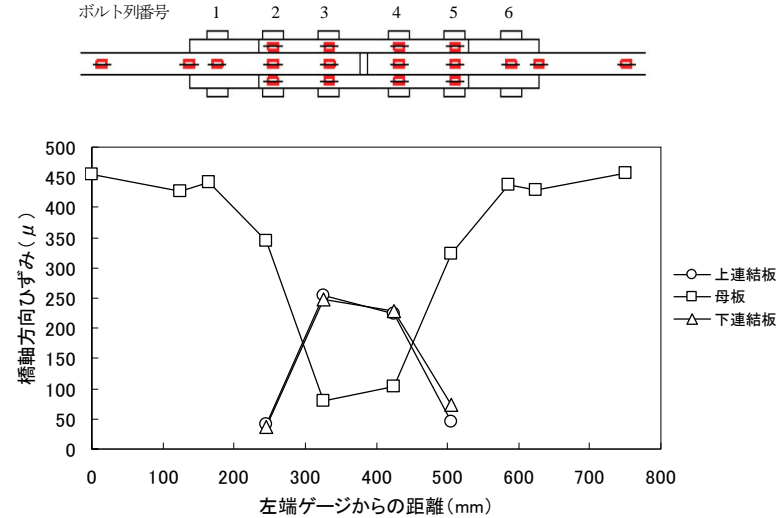

(a) Type-1 $200 \mathrm{kN}$

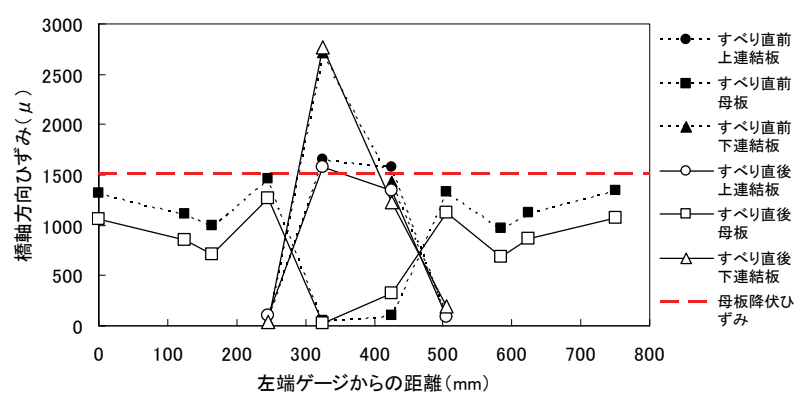

(c) Type-1 一回目すべり前後

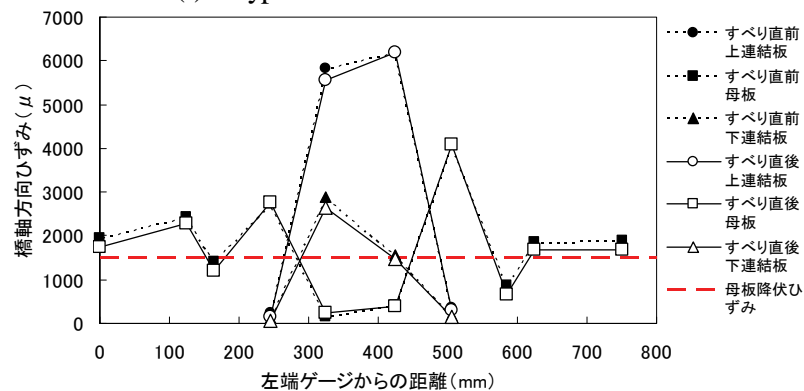

(e) Type-1 二回目すべり前後

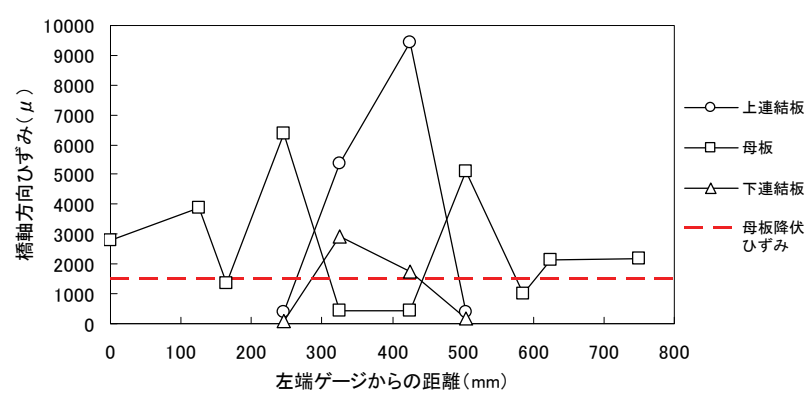

(g) Type-1 床版圧壊
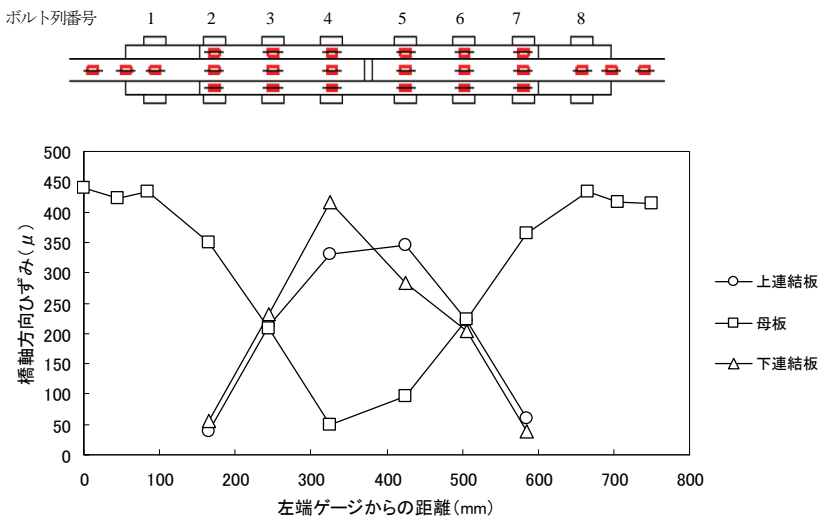

(b) Type-2 $200 \mathrm{kN}$

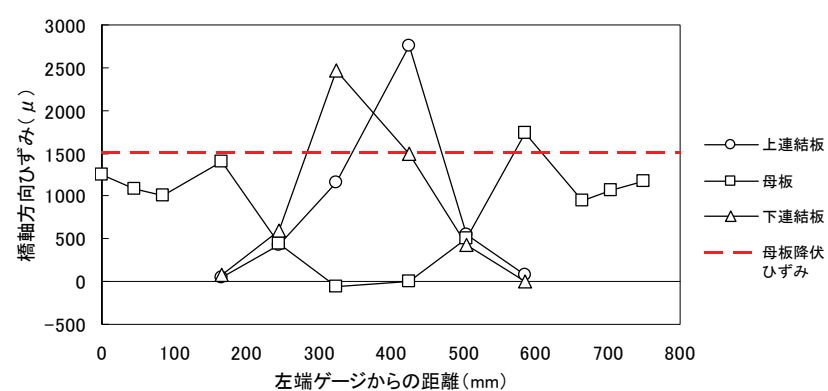

(d) Type-2 母板降伏

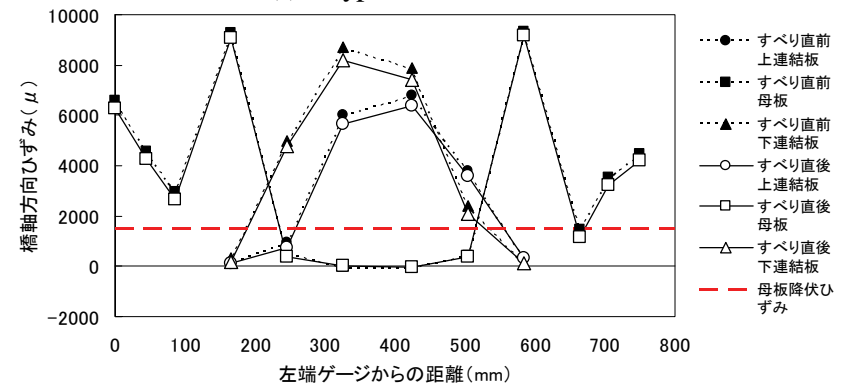

(f) Type-2 すべり前後

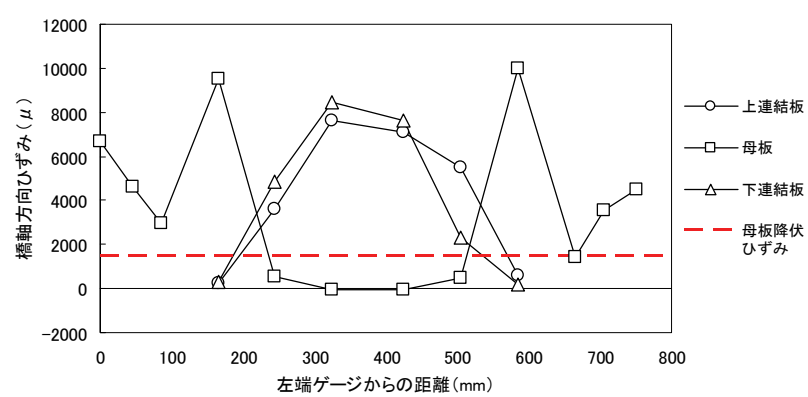

(h) Type-2 床版圧壊

図-16 下フランジのひずみ分布

\section{c) 下フランジ母板と連結板のひずみ}

図-16に，Type-1および Type-2の下フランジ母板と連 結板のひずみ分布をそれぞれ示す，母板のひずみが接合 部中央へ行くほど減少し，逆に連結板では，中央部に行 くほどひずみが大きくなる傾向が確認できる.このこと は，下フランジ母板から上下の連結板に荷重が伝達され ていることを示している.
ただし，連結板のサイズがType-1では小さく，応力伝 達がより内側（第3列と第4列ボルト間）で主として行わ

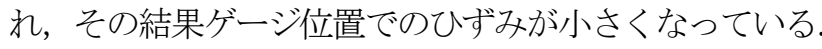
すべり先行型であるType-1では，す心゙り発生以降，連結 板のひずみが極めて大きくなっている．特に上側の連結 板におけるひずみは非常に大きくなっている。これは, 一回のすべりでは，下フランジボルトが完全な支圧状態 
とはならずに，主として上側の連結板が局所的に支圧状 態に移行しているためと考えられる．また，二回目す心゙ り後では下側の連結版のひずみがさらに大きくなってお り，主として下側の連結板を介して荷重伝達が行われて いると考えられる.

一方，降伏先行型であるType-2では，Type-1のような 大きなひずみ分布の変化が認められず，孔引きの関係か ら母板では第2列・第7列ボルト位置での降伏が進展して

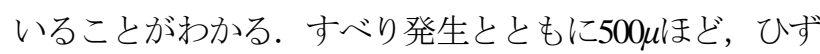
みが減少しているが，それ以外ではひずみの減少は見ら れず，それ以前に部分すべりが下フランジ内で発生して いた様子は認められない。

\section{（3）すべり先行型モデルと降伏先行型モデルの力学的 挙動の比較}

実験結果のまとめを表-4 に示す． $P_{y}$ および $\delta_{y}$ は下フ ランジ降伏時の荷重と支間中央の鉛直変位（測定值）, $P_{\text {max }}$ および $\delta_{\text {max }}$ は最大荷重とその時点での支間中央の鉛

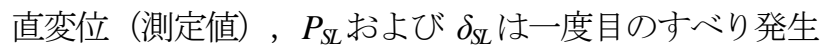
時の荷重と支間中央の鉛直変位（測定値）， $P_{u}$ および $\delta_{u}$ はコンクリート圧縮破壊時の荷重と支間中央の鉛直変位

(測定値），である．全ての測定值は，式(5)により求 めた純断面部分降伏時の荷重の計算値 $P_{y n}$, およびその 時点における支間中央の鉛直変位の計算值 $\delta_{y n}$ により無 次元化している. $\delta_{\mathrm{yn}}$ は, 式(5)より算出した結果,

15.6mmであった.

最大荷重については，すべり先行型である Type-1，降 伏先行型である Type-2 ともにほぼ同じであり, 降伏先 行型である Type-2 の方が約 4\%大きくなった. Type-1 の 最大荷重が低くなったのは，早期にすべりが発生し，橋 軸方向の変位が大きくなったことで，試験区間での曲率 が増加し，コンクリートのひずみが増大したことが原因 と考えられる. そのため, 最大荷重時の変位については, すべり先行型である Type-1 の方がやや大きくなってい る.

最大荷重時における腹板 B 断面のひずみ分布を比較 すると降伏先行型である Type-2 の方が発生するひずみ は大きく, すべり先行型である Type-1 の約 2〜6倍とな った. これは，Type-1では寸べりが発生したことで，支 圧状態となり荷重をボルト孔近傍で局所的に分担したが, Type-2 では最大荷重までには主すべりが発生せず，応力 再配分をしながら母板および連結板全体で荷重を分担し たためと考えられる.

以上のことから, 合成桁の高力ボル卜摩擦接合継手の 設計を考えた場合，本実験によれば，最大荷重および床 版圧壊時の荷重は降伏先行型およびすべり先行型ともほ ぼ同レベルであり，いずれの設計方針においても AASHTO の終局モーメントをほぼ珮足する.ただし，
表-4 荷重/降伏荷重および変位降伏変位

\begin{tabular}{|l|c|c||l|c|c|}
\hline 荷重 & Type-1 & Type-2 & 変位 & Type-1 & Type-2 \\
\hline$P_{y} / P_{y n}$ & 1.14 & 1.03 & $\delta_{y} / \delta_{y n}$ & 1.62 & 1.29 \\
\hline$P_{\max } / P_{y n}$ & 1.38 & 1.42 & $\delta_{\max } / \delta_{y n}$ & 2.85 & 2.33 \\
\hline$P_{S L} / P_{y n}$ & 1.08 & 1.42 & $\delta_{S L} / \delta_{y n}$ & 1.19 & 2.33 \\
\hline$P_{u} / P_{y n}$ & 1.38 & 1.34 & $\delta_{u} / \delta_{y n}$ & 2.85 & 3.16 \\
\hline
\end{tabular}

降伏先行型で設計した場合，すべり先行型に比べ，す心゙ り字の変位が 1 回目す心゙り字の変位に比べ約 2 倍, 床版 圧壊時の変位が約 1.1 倍となり, 変形がやや大きくなる 傾向にある.

\section{3. 合成椼接合部のすべりモーメントの試算}

\section{(1) 試算方法}

本節では，非合成桁で行われているすべり耐力の試算 方法 ${ }^{16}$ をとに, 合成桁高力ボルト摩擦接合部のす心゙り 耐力の試算を行った.

平面保持の仮定に従い，ひずみが線形に分布すると仮 定する. 下フランジおよび腹板接合部にすべりが発生す る時の中立軸位置周りの作用モーメントを式(5)より算 出する.

$$
\begin{gathered}
M_{S L}=\sum\left(\phi_{s} \times \phi_{m} \times h_{i} \times \rho_{i}\right)+\int_{A_{c}} \sigma_{c} d A \times h_{c} \\
\rho_{i}=\int_{A_{i}} \sigma_{i} d A, \quad\left|\rho_{i}\right| \leq \rho_{l i} \\
\rho_{l i}=\rho_{s} \times m \times n, \quad \rho_{s}=\mu \times N
\end{gathered}
$$

ここに,

$\phi_{s} \quad:$ すべり耐力補正係数(1.0)

$\phi_{m} \quad$ : すべり耐力補正係数(曲げモーメント)(フラン ジ部 : 1.0, 腹板部 : 0.8)

$h_{i}$ : 中立軸から $i$ 行目高力ボルト図心位置までの 距離

$\sigma_{c} \quad$ : コンクリート床版の圧縮応力

$A_{c} \quad$ : コンクリート床版の断面積

$h_{c}$ : 中立軸からコンクリート床版図心位置まで の距離

$\rho_{i} \quad: i$ 行目が伝達する力

$\sigma_{i} \quad: i$ 行目が伝達寸る応力

$A_{i} \quad: i$ 行目が応力伝達を分担する母材の断面積

$\rho_{l i} \quad: i$ 行目のすべり耐力

$\rho_{s}$ : ボルト一本一接合面あたりの基本すべり耐 力

$m$ : 接合面の数

$n \quad$ : 各ボルト行の高力ボルト本数 


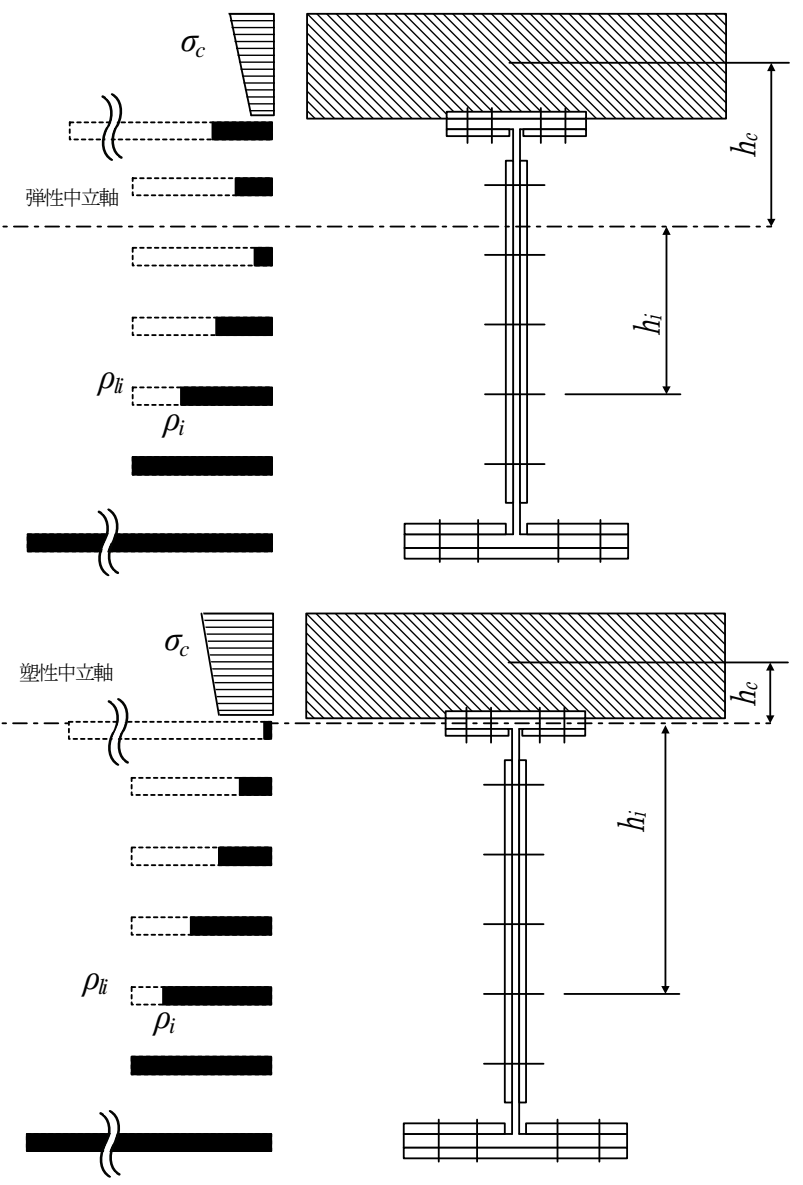

図-17 ボルト位置における接合部の伝達力分布と 床版応力

$N$ : M22F10T の設計標準軸力 $(=205 \mathrm{kN})$

$\mu \quad$ : すべり係数(=0.43，標準すべり試験結果によ る)

このとき，作用モーメントを計算するための中立軸に は，すべり先行型では弾性中立軸を，降伏先行型ではす ベり以前に中立軸がすでに移動していることから塑性中 立軸を使用して算出した。ただし，作用モーメントを算 出するために使用した桁断面は総断面とし，中立軸位置 の計算にもこれを用いている．算出の際に用いたボルト 位置における接合部の伝達力分布と床版応力の模式図を 図-17 に示す。立軸から接合部までの距離 $h_{i}$ は，フラ ンジ部分は板厚中心まで，腹板はボルト図心位置までと した．表-5 にすべりモーメントの試算結果を実験結果 と合わせて示す.

PSL- $f$ は下フランジがすべり耐力に到達する作用モー メントを荷重に変換した值であり，PSL-wn は腹板 $n$ 行 目のボルト行がすべり耐力に到達する作用モーメントを 荷重に変換した值である．ただし， $n$ が大きくなるとす ベり耐力が実験結果の最大荷重を上回るため, Type-1 で はPSL-w4まで, Type-2では PSL-w2まで算出した.

次に，接合部各部がすべてすべり耐力に到達する場合
表-5 試算結果の比較

\begin{tabular}{|c|c|c|}
\hline 荷重レベル & Type-1(kN) & Type-2(kN) \\
\hline$P S L-f$ & 418 & $530^{*}$ \\
\hline$P S L-w 5$ & 440 & $407^{*}$ \\
\hline$P S L-w 4$ & 622 & $555^{*}$ \\
\hline$P S L-w 3$ & - & $574^{*}$ \\
\hline$P S L-w 2$ & - & $603^{*}$ \\
\hline$P u S L$ & $527^{*}$ & $652^{*}$ \\
\hline 実験結果 & $\begin{array}{l}1 \text { 回目 : } 455 \\
2 \text { 回目 : } 552\end{array}$ \\
\hline
\end{tabular}

* : 中立軸位置を塑性中立軸位置とし

て算出した值

を仮定し，塑性中立軸位置におけるすべりモーメント （終局すべり耐力 PUSL）を同様に計算した。コンクリ 一ト床版は圧縮強度の 0.85 倍の等価応力ブロックにて 計算を行った.

ここでは，すべり耐力に到達したボルト行では，それ 以上の荷重を負担できないと仮定して算出している.

Type-2 では，ひずみが線形分布すると仮定すると，ボル ト本数が多い下フランジ接合部よりも腹板 5 行目ボルト が先行してすべり耐力に到達するため, PSL-fよりも PSL-w5の方が值が小さくなっている.

\section{(2) 試算結果の評価}

すべり先行型である Type-1 は，実験結果より降伏荷 重に達する前に，下フランジ接合部と腹板 5 行目ですべ り（一回目）が発生しており，その荷重レベルは腹板 5 行目までがすべると仮定して算出した PSL-w5 とほぼ同 程度となった。 これは，すべり先行型において，下フラ ンジ接合部と腹板の一部がすべり，最終的に桁全体です ベるという現象を表しているものと考えられる. Type-1 はこの後荷重が増加し, 再びすべりが発生しているが, その荷重レベル（552kN） は，塑性中立軸位置で求めた 終局すべり荷重である PuSL（527kN） とほぼ同じとなっ た. 図-15(a)から一回目すべりによって，中立軸が上昇 することが確認されており，塑性中立軸を使用したす心゙ り耐力が実験結果に近い值を与えると推察できる.

降伏先行型である Type-2 では，すべり荷重は，降伏 荷重に達した後, 腹板 2 行目までがす心゙ると仮定したす ベり而力(PSL-w2)とほぼ等しくなった. 図-15(d)でも腹板 第 2 行目以下がすべっているのが確認できる．一方，塑 性中立軸に関して求めた終局すべり耐力 PuSL には到達 しなかった。 これは，鋼析の降伏によるすべり係数の低 下が影響しているものと考えられる. 


\section{4. まとめおよび課題}

本研究では, 高力ボルト摩擦接合継手を有する合成桁 の曲げ挙動の解明を目的として，すべり先行型（Type-1, $\beta=0.81$ ） と降伏先行型（Type-2, $\beta=1.1 ）$ の摩擦接合部を 有するコンパクト断面合成桁の曲げ載荷実験を行った.

さらに，合成桁高力ボルト摩擦接合部のす心゙り耐力の試 算を行い，その設計法について議論した. 本研究で得ら れた結論を以下に示寸.

(1) すべり先行型では, 下フランジと腹板最下行のみが 部分すべりを起こす。この時，残りのボルトはすべ らずに固着状態であるが，その後の荷重増大に伴い 腹板全体がすべり耐力に達した時点で主すべりが発 生する.

（2）降伏先行型では，下フランジ接合部母板の降伏がま ず発生し，その後下フランジ接合部とともに腹板下 部の接合部がすべりを発生する．また主すべりが発 生するまでにも, 腹板内で部分すべりが発生したも のと考えられる.

(3) すべり先行型の終局荷重は総断面での AASHTO に よる終局モーメントの 97\%であった。これは主にす ベりによる床版ひずみの増大が影響している.

（4）降伏先行型の最大荷重は総断面での AASHTOによ る終局モーメントにほほ到達した，その最大荷重は 桁の塑性化や床版圧壊に起因するものではなく，す べり発生によるものであった.

（5）すべり先行型では，一回目すべりが発生した荷重は PSL-w5 とほぼ同じレベルとなった。二回目す心゙り である主すべり時の荷重は，PuSL と同程度の值が 得られた。

(6) 降伏先行型では, 終局すべり荷重 PuSL には到達し なかった。これは，母材が降伏し，板厚減少が顕著 となりそれに伴う軸力低下が原因となり，すべり荷 重が低下したと考えられる，また，下フランジより も腹板 5 行目が先行してすべりが発生するボルト配 置であることから，腹板において部分すべりが発生 したと考えられる. その後, 主すべり発生荷重は腹 板 2 行目ボルトがすべり耐力に達する PSL-w2 に相 当する.

(7) 合成栴の高力ボルト摩擦接合継手の設計を考えた場 合，本実験によれば，最大荷重および床版圧壊時の 荷重は降伏先行型およびすべり先行型ともほぼ同レ ベルであり，いずれの設計方針においても AASHTO の終局モーメントをほぼ満足する．ただ し，降伏先行型で設計した場合，すべり先行型の場 合に比べ，すべり時の変位が 1 回目すべり時の変位 に比べ約 2 倍, 床版圧壊時の変位が約 1.1 倍となり, 変形がやや大きくなる傾向にある.
(8) 降伏先行型，すべり先行型のいずれの設計方針にお いても, 高力ボルト摩擦接合継手部の存在が合成桁 の終局荷重に影響を与えることがないことが確認で きた. 特に，すべり先行型においては，支圧状態に 移行し，その結果，降伏先行型と同等の終局荷重を 得ることができたと考えられる.

以上が本研究で得られた主な結果であるが，断面形状 なども限られており,さらなる研究を必要とする. 今後 は，すべりが先行して発生した場合に，そのすべりが最 大強度に及ぼす影響や適切なボル卜配置などを載荷実験 や FEA によって検討し，定量的に明らかにする必要が ある.

\section{参考文献}

1) Gupta, V.K., Okui, Y. and Nagai, M. : Development of web slenderness limits for composite I-girders accounting for initial bending moment, 土木学会論文集 A, Vol.62, No.4, pp.854-864, 2006.10.

2) Gupta, V.K., Okui, Y., Inaba, N. and Nagai, M. : Effect of concrete crushing on flexural strength of steel-concrete composite girders, 土木学会論文集 A, Vol.63, No.3, pp.475-485, 2007.7.

3) 稲葉尚文, 奥井義昭, 長井正嗣, 本間淳史, 春日井俊 博, 野呂直以：合成 I 桁の曲げ, せん断相関強度解明 に関する実験的研究，土木学会論文集 A, Vol.66, No.2, pp.393-405, 2010.6.

4) 石川誠, 亀井義典, 西村宣男 : 曲げを受ける鋼 I 桁高 カボルト継手部のすベり挙動解析, 土木学会第 58 回 年次学術講演会, I-161, pp. 321-322, 2003.9.

5) 平山博, 徳力健, 長井正嗣, 奥井義昭: 合成桁中間支 点部の曲げ強度評価に関する一考察, 土木学会第 64 回年次学術講演会, I-439, pp. 877-878, 2009.9.

6) 日本鋼構造協会 : 合成桁の限界状態設計試案, JSSC テクニカルレポート, No.70, 2006.10.

7) AASHTO: LRFD Bridge design specifications, 2005interim revisions, Washington, D.C., 2005.

8) European Committee for Standardization (CEN): Eurocode 0, Basis of structural design, EN 1990, 2002.

9) European Committee for Standardization (CEN): Eurocode 3, Design of steel structures, Part 1.8, Design of joints, EN 1993-1-8, 2005.

10) 日本道路協会 : 道路橋示方書 - 同解説, I 共通編 II 鋼橋編, 2000.

11) 新都市社会技術融合創造研究会・橋梁のコス卜縮減構 造に関する研究会 : 橋梁のコスト縮減に向けての現状 と展望, 2007.

12) 西村宣男, 秋山寿行, 亀井義典 : 高力ボルト摩擦接合 継手に関する最近の研究動向, 土木学会論文集, 
No.675/I-55, pp. 1-14， 2001.4

13) 松岡徹 : 合成桁高力ボルト摩擦接合部の曲げ強度解明 に関する実験的研究, 長岡技術科学大学, 修士論文, 2009.2.

14) 日本規格協会 : JIS B 1186-1995 摩擦接合用高力六角 ボルト・六角ナット・平座金のセット解説，1995.3.

15) 土木学会鋼構造委員会 高力ボルト摩擦接合継手の設計
法に関する調査検討小委員会 : 高力ボルト摩擦接合継

手の設計・施工・維持管理指針(案), 2006.12 .

16) 土木学会鋼構造委員会 鋼・合成構造標準示方書小委員 会 : 2007 年制定鋼・合成構造標準示方書[総則編, 構 造計画編，設計編]，2007.3.

\section{EXPERIMENTAL STUDY ON MECHANICAL BEHAVIOR OF THE COMPOSITE STEEL GIRDER WITH HIGH STRENGTH BOLTED FRICTIONAL JOINTS SUBJECTED TO BENDING}

\section{Takashi YAMAGUCHI, Masatsugu NAGAI, Takeshi MIYASHITA, Yoshihiko TODA, Natsuki YOSHIOKA and Toru MATSUOKA}

Generally speaking, it is possible to make the cross section small and to reduce $20 \%$ of the weight of the steel girder by adoption of Euro code/AASHTO-LRFD to the composite girder subjected to positive bending moment. Therefore, the new design method for connections which can deal with the ultimate state after major slip is needed from the viewpoint of further rationalization of the composite steel girder bridge design.

Therefore, at Nagaoka University of Technology, the basic experiment has been carried out by authors in order to investigate the behavior of such a connection after major slip. In this study, in order to collect basic information for design of composite girder connection. Finally, based on these results, the evaluation method of ultimate bending strength of the composite girder with high strength bolted friction joints are proposed and desirable design concept of the friction type joints for composite girder bridges are summarized. 